\title{
Coprophilous myxomycetes: updated summary, key to species, and taxonomic observations on Trichia brunnea, Arcyria elaterensis, and Arcyria stipata
}

\author{
UNO H. ELIASSON and HAROLD W. KELLER
}

ELIASSON, U. H. \& KELLER, H. W. 1999: Coprophilous myxomycetes: updated summary, key to species, and taxonomic observations on Trichia brunnea, Arcyria elaterensis, and Arcyria stipata. - Karstenia 39:1-10. Helsinki. ISSN 0435-3402

An updated summary is provided for myxomycete species occurring on dung of herbivorous animals. At least 99 species representing 23 genera have been reported. Most species normally occur on other substrata and are only occasionally found on dung. A restricted number of species are truly coprophilous in that most or all records are from this substratum. These species are Arcyria elaterensis, Badhamia apiculospora, $B$. rhytidosperma, B. spinispora, Didymium annulisporum, D. nullifilum, D. rugulosporum, Kelleromyxa fimicola, Licea alexopouli, Licea pescadorensis, Machrideola coprophila, Perichaena corticalis var. liceoides, P. luteola, Trichia brunnea, and $T$. fimicola. A key is provided for species which are truly coprophilous or often found on dung. All species ever reported on dung are listed. Hemitrichia stipata var. fusca Z.Moravec is conspecific with Trichia brunnea J.J.Cox. Taxonomic comments are given on Arcyria elaterensis and A. stipata, and the taxonomic importance of dextrorse versus sinistrorse spiral ornamentation on the capillitial threads is discussed.

Key words: Coprophilous myxomycetes, capillitial ornamentation, Arcyria elaterensis, Arcyria stipata, Trichia brunnea

Uno H. Eliasson, Botanical Institute, Götehorg University, Box 461, SE 40530 Göteborg, Sweden

Harold W. Keller, Department of Biology, Central Missouri State University, Warrensburg, Missouri 64093, and Botanical Research Institute of Texas, 509 Pecan Street, Fort Worth, Texas 76102-4060, U.S.A.

\section{Introduction}

Myxomycetes grow on a wide range of substrata and in many different habitats. Although no correlation is absolute, the majority of species show preferences for a special kind of substratum and, to varying degree, a special microhabitat. The largest number of species are found on decaying wood, bark and leaf litter. Other species occupy different, and sometimes rather distinct ecological niches, such as living bryophytes, bark of living trees, living leaves of tropical angiosperms, or various living or dead plant material under or in close contact with melting snow. A relatively large number of species have been recorded on dung of herbivorous animals. The vast majority are species that normally occur on other substrata and are only occasionally and rarely found on dung. A limited number of species can be regarded as truly coprophilous in the sense that most or all records are from this substratum, namely, $A r$ cyria elaterensis, Badhamia apiculospora, $B$. rhytidosperma, B. spinispora, Didymium annulisporum, D. nullifilum, D. rugulosporum, Kelleromyxa fimicola, Licea alexopouli, Licea pescadorensis, Macbrideola coprophila, Perichaena corticalis var. liceoides, P. luteola, Trichia brunnea, and T. fimicola. 
This paper summarizes records of coprophilous myxomycetes based on our observations and available literature. The number of species recorded on dung varies widely among genera. For example, the list comprises 20 species of $\mathrm{Di}$ dymium, whereas Cribraria, despite over 35 species in the genus, is represented by a single record of $C$. violacea (Hertel 1962).
There are relatively few papers dealing explicitly with coprophilous myxomycetes. Ecological aspects and descriptions of moist chamber techniques are provided in Eliasson \& Lundqvist (1979) and Krug et al. (in press). Other publications centering on coprophilous species are those of Merrill (1969), García-Zorrón (1977), Nannenga-Bremekamp et al. (1979), Cox (1981), and Chung \& Liu (1995, 1996).

\section{Key to coprophilous myxomycete species}

Only myxomycete species that are exclusively or repeatedly recorded on dung are included in this key. For additional records of species known to occur on dung see the comprehensive list of species.

1 Capillitium lacking or consisting only of occasional simple threads attached to the peridium; fructifications sporangiate, never exceeding $0.5 \mathrm{~mm}$ in height .... 2

- Capillitium present; fructifications often larger, variable in size and shape

2 Sporangia spindle-shaped, erect on a constricted base Kelleromyxa fimicola

- Sporangia hemispherical to globose 8

3 Sporangia stalked; columella large, globose Macbrideola coprophila

- Sporangia sessile; columella never present. Didymium nullifilum

4 Peridium with yellow or whitish scales of calcium carbonate crystals $m$

- Peridium without calcareous scales 5

5 Spore wall thinner and spores paler on one side; sporangia $0.2-0.4 \mathrm{~mm}$ in diam...... Licea tenera

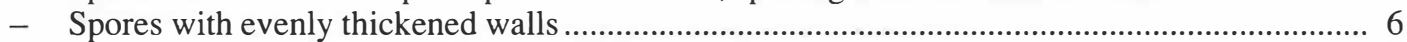

6 Sporangia $0.06-0.15 \mathrm{~mm}$ in diam.; capillitium lacking ............................................................. 7

- Sporangia 0.3-0.5 mm in diam; capillitium, if present, of simple threads attached to peridium

Perichaena corticalis var. liceoides

7 Peridium black, smooth, shiny; spores $9.5-11 \mu \mathrm{m}$ in diam. Licea alexopouli

- Peridium reddish brown to black; spores 7-8 $\mu \mathrm{m}$ in diam. when globose, $8-10 \times 7-8 \mu \mathrm{m}$ when ovoid

Licea pescadorensis

8 Calcium carbonate lacking in all parts of the fructification ................................................... 9

- Calcium carbonate present, as crystals or amorphous granules, in the peridium and/or capillitium

9 Sporangia minute, globose, $40-50 \mu \mathrm{m}$ in diam., long-stalked; spore mass whitish or pink Echinostelium minutum

- Sporangia or plasmodiocarps variable in size and shape, $0.2 \mathrm{~mm}$ or more in diam., sessile or stalked....

10 Peridium disappearing; sporangia elongate or cylindric with spore mass dark brown to blackish; capillitium forming peripheral surface net Stemonitis fusca

- Peridium partially persistent in mature fructifications, at least at base of sporangium; spore mass grey, brown, or brightly coloured

11 Capillitium at least partly of free, unbranched elaters with spiral ornamentation ...................... 12

- Capillitium branched, sometimes forming a network; free elaters, if present, without spiral ornamentation

12 Capillitial threads with 2 spiral bands Trichia fimicola

- Capillitial threads with 3 or 4 spiral bands 13

13 Sporangia dark olivaceous brown; peridium iridescent Trichia brunnea

- Sporangia yellowish brown; peridium not iridescent Arcyria elaterensis 
14 Peridium in mature fructifications persistent as shallow cup at base of sporangium; spores mostly whitish or grey in mass .............................................................. Arcyria cinerea

- Peridium persistent above and below, lacking a basal cup .................................................... 15

15 Fructifications predominantly plasmodiocarpous; capillitial threads spiny

Perichaena chrysosperma

- Fructifications predominantly sporangiate; capillitial threads not spiny

16 Dehiscence circumscissile; peridium not translucent. 16

- Dehiscence irregular; peridium translucent ......................................................................... 17

17 Capillitium well developed, forming a network Perichaena luteola

- Capillitium sparse, mostly of simple or sparsely branched threads attached to the peridium .................................................... Perichaena corticalis var. liceoides

18 Capillitium calcareous throughout or at nodes ...................................................................... 19

- Capillitium not calcareous .................................................................................................... 26

19 Capillitium calcareous throughout or almost so, forming a network or a system

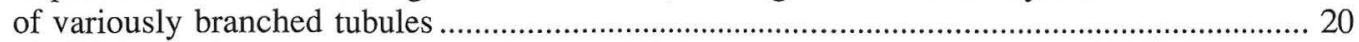

- Capillitium calcareous only at nodes ................................................................................. 22

20 Spores globose, wrinkled-reticulate over about half the surface ......... Badhamia rhytidosperma

- Spores oval with ridge along one side, surface not reticulate .................................................. 21

21 Spores spiny, spines up to $1 \mu \mathrm{m}$ long ................................................... Badhamia spinispora

- Spores smooth or almost so ............................................................. Badhamia apiculospora

22 Fructifications aethalioid, $1-5 \mathrm{~mm}$ in extent when on dung; spores predominantly elliptic Fuligo cinerea

- Fructifications sporangiate or plasmodiocarpous ................................................................. 23

23 Fructifications plasmodiocarpous, often closely aggregated and convoluted Physarum gyrosum

- Fructifications predominantly sporangiate ......................................................................... 24

24 Sporangia strongly compressed laterally ............................................. Physarum compressum

- Sporangia rounded to cylindric or ovoid, not laterally compressed

25 Sporangia sessile, pulvinate 25

- Sporangia cylindric or ovoid, mostly attached to substratum by weak stalklike extensions of the hypothallus Physarum didermoides

26 Calcium crystals on peridium united into a smooth shell-like crust ......................................... 27

- Calcium crystals powdering peridium or forming aggregated scales ......................................... 29

27 Spores 18-20 $\mu \mathrm{m}$, coarsely warted .................................................. Didymium rugulosporum

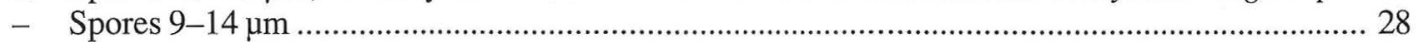

28 Spores minutely warted or almost smooth, $11-14 \mu \mathrm{m}$ in diam., spore wall normally with a thicker portion on one side Didymium difforme

- Spores coarsely and irregularly warted, 9-10 $\mu \mathrm{m}$ in diam.

29 Fructifications sessile, plasmodiocarpous or sporangiate

- Fructifications stalked, sporangiate ..................................................................................... 32

30 Outer peridial wall crustose, distant from membranous inner peridium; fructifications sporangiate.

Didymium karstensii

- Peridial layers closely associated 31

31 Peridium mostly covered with a white floccose crust of calcium crystals; capillitium abundant, rigid; spores distinctly and closely warted; fructifications predominantly plasmodiocarpous Didymium dubium

- Peridium covered with a layer of calcium scales; capillitium sometimes poorly developed or lacking; spores with widely scattered spines up to $1 \mu \mathrm{m}$ long ................. Didymium nullifilum

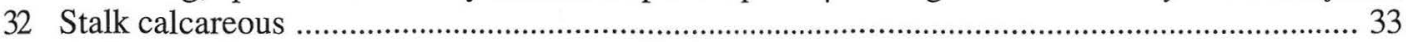

- Stalk not calcareous .......................................................................................................... 34

33 Columella small, pulvinate, often spiny; stalk, if present, very short .......... Didymium karstensii

- Columella discoid to hemispheric; stalk mostly well developed ........... Didymium squamulosum

34 Columella dark brown Didymium nigripes 
- Columella yellow or white 35

35 Columella yellow, stalked; capillitial threads with dark swellings

Didymium ovoideum

- Columella white, not stalked; capillitial threads without dark swellings Didymium iridis

\section{Comprehensive list of species recorded on dung}

Species are listed in alphabetical order. Species included in the key have been marked with an asterisk. The list includes all species that, to our knowledge, have been recorded on dung. For species without references, see Eliasson \& Lundqvist (1979). References where species are treated in more detail are given in some cases. Author abbreviations follow Brummitt \& Powell (1992).

Arcyodes incarnata (Alb. \& Schwein.) O.F.Cook *Arcyria cinerea (Bull.) Pers.

*Arcyria elaterensis Mulleavy Arcyria incarnata (Pers.) Pers.

Arcyria leiocarpa (Cooke) G.W. Martin \&

Alexop.

Arcyria pomiformis (Leers) Rostaf.

Arcyria stipata (Schwein.) Lister

*Badhamia apiculospora (Härk.) Eliasson \& N.Lundq. (Physarum apiculosporum Härk., Badhamia semiannulata Raub \& H.W.Keller)

Badhamia gracilis (T.Macbr.) T.Macbr. (Blackwell \& Gilbertson 1980)

Badhamia macrocarpa (Ces.) Rostaf.

Badhamia ovispora Racib. (Merrill 1969). This is a doubtful record probably referring to Badhamia apiculospora. Mainly due to Raciborski's partially inaccurate description of $B$. ovispora, two species have been referred here. The true identity of the species was clarified by Keller et al. (1975). It is apparently a rarely encountered species, probably mainly occurring on decaying wood or bark.

*Badhamia rhytidosperma H.W.Keller \& Schokn. (Keller \& Schoknecht 1989c)

*Badhamia spinispora (Eliasson \& N.Lundq.) H.W.Keller \& Schokn. (Physarum spinisporum Eliasson \& N.Lundq.) (Eliasson \& Lundqvist 1979, Keller \& Schoknecht 1989b)

Calomyxa metallica (Berk.) Nieuwl. (Cox 1981)

Colloderma oculatum (C. Lippert) G.Lister (García-Zorrón 1977)

Comatricha mirabilis R.K.Benj. \& Poitras

Comatricha nigra (Pers.) J.Schröt.
Comatricha pulchella (C.Bab.) Rostaf.

Craterium leucocephalum (Pers.) Ditmar

Cribraria violacea $\mathrm{Rex}$

Diderma applanatum Fr.

Diderma effusum (Schwein.) Morgan

Diderma globosum Pers.

Diderma niveum (Rostaf.) T.Macbr.

Diderma radiatum (L.) Morgan (Singh 1984)

Diderma simplex (J.Schröt.) G.Lister

Diderma testaceum (Schrad.) Pers.

Didymium anellus Morgan

Didymium annulisporum H.W.Keller \& Schokn.

(Keller \& Schoknecht 1989a)

Didymium cf. bahiense Gottsb. (Gøtzsche 1989)

Didymium clavus (Alb. \& Schwein.) Rabenh.

*Didymium difforme (Pers.) S.F.Gray

*Didymium dubium Rostaf.

*Didymium iridis (Ditmar) Fr. (Blackwell \& Gilbertson 1980)

*Didymium karstensii Nann.-Bremek. (Merrill 1969, Cox 1981)

Didymium megalosporum Berk. \& T.Macbr. (Zeller \& Tóth 1977)

*Didymium nigripes (Link) Fr. (Zeller \& Tóth 1977)

*Didymium nullifilum (Kowalski) M.L. Farr (Squamuloderma nullifila Kowalski) (Farr 1982)

Didymium ochroideum G.Lister

*Didymium ovoideum Nann.-Bremek. (Cox 1981) Didymium quitense (Pat.) Torrend (NannengaBremekamp et al. 1979)

*Didymium rugulosporum Kowalski

Didymium saturnus H.W.Keller (Lakhanpal \& Mukerji 1978)

*Didymium squamulosum (Alb. \& Schwein.) Fr.

*Didymium trachysporum G.Lister

Didymium vaccinum (Durieu \& Mont.) Buchet

Didymium verrucosporum A.L. Welden

*Echinostelium minutum deBary (Critchfield \& Demaree 1991, Blackwell \& Gilbertson 1980)

*Fuligo cinerea (Schwein.) Morgan (Zeller \& Tóth 1977)

Fuligo septica (L.) F.H. Wiggers (Blackwell \& 
Gilbertson 1980)

*Kelleromyxa fimicola (Dearn. \& Bisby) Eliasson (Licea fimicola Dearn. \& Bisby) (Eliasson et al. 1991)

Lamproderma scintillans (Berk. \& Broome) Morgan

Leocarpus fragilis (Dicks.) Rostaf.

Lepidoderma chailletii Rostaf. (Zeller \& Tóth 1977)

*Licea alexopoulim Blackw.

Licea cf. belmontiana Nann.-Bremek.

*Licea pescadorensis C.-H.Chung \& C.-H.Liu

Licea punctiformis Martin (García-Zorrón 1977, Lakhanpal \& Mukerji 1981)

Licea pusilla Schrad.

* Licea tenera Jahn (Kowalski \& Curtis 1968, Lakhanpal \& Mukerji 1975, García-Zorrón 1977, Mitchel \& Chapman 1980, Cochet \& Bozonnet 1984)

Licea variabilis Schrad.

Lycogala epidendrum (L.) Fries (Singh 1984)

* Macbrideola coprophila Nann.-Bremek., Mukerji \& Singh (Nannenga-Bremekamp et al. 1979)

Macbrideola cornea (G.Lister \& Cran) Alexop.

*Perichaena chrysosperma (Currey) Lister

*Perichaena corticalis (Batsch) Rostaf. var. corticalis (Zeller \& Tóth 1977)

* Perichaena corticalis var. liceoides (Rostaf.) Lister (Perichaena liceoides Rostaf.) (Gilert 1990)

Perichaena depressa Libert (Zeller \& Tóth 1977)

* Perichaena luteola (Kowalski) Gilert (Calonema luteolum Kowalski, Arcyodes luteola (Kowalski) Nann.-Bremek.) (Rammeloo 1978, Gilert 1995)

Perichaena minor (G.Lister) Hagelst. (Cox 1981, Critchfield \& Demaree 1991)

Perichaena pedata (Lister) G.Lister

Perichaena quadrata T.Macbr. (Keller \& Eliasson 1992)

Perichaena syncarpon T.E.Brooks

Perichaena vermicularis (Schwein.) Rostaf.

Physarum cf. bitectum G.Lister

Physarum bivalve Pers. (Ing \& Spooner 1994)

Physarum cf. brunneolum (W.Phillips) Massee (Stephenson 1989)

Physarum cinereum (Batsch) Pers. (Zeller \& Tóth 1977, Gøtzsche 1989)

*Physarum compressum Alb. \& Schwein.

Physarum confertum T.Macbr.

Physarum contextum (Pers.) Pers. (incl. P. mucosum Nann.-Bremek.)
Physarum diderma Rostaf. (Zeller \& Tóth 1977)

*Physarum didermoides (Pers.) Rostaf. (Zeller \& Tóth 1977)

* Physarum gyrosum Rostaf. (Cox 1981)

Physarum cf. leucophaeum Fr. (Gøtzsche 1989)

Physarum leucopus Link

Physarum nucleatum Rex

Physarum nutans Pers.

* Physarum ovisporum G.Lister (Cox 1981)

Physarum pusillum (Berk. \& M.A.Curtis)

G.Lister (Blackwell \& Gilbertson 1980)

*Stemonitis fusca Roth

Stemonitis herbatica Peck (Chung \& Liu 1995)

Stemonitis pallida Wingate

Stemonitis smithii T.Macbr. (Chung \& Liu 1995, as $S$. axifera var. smithii (T.Macbr.) Hagelst.)

Trichia botrytis (J.F.Gmel.) Pers.

*Trichia brunnea J.J.Cox (Cox 1981)

(Hemitrichia stipata var. fusca Z.Moravec)

Trichia contorta (Ditmar) Rostaf.

*Trichia fimicola (Marchal) Ing (T. varia var. fimicola Marchal) (Ing 1967)

Trichia varia (Pers.) Pers.

\section{Dubious taxon}

Physarum fimetarium Schum. Name rejected by Eliasson \& Lundqvist (1979) as a nomen dubium.

\section{Taxonomic observations}

Spiral ornamentation on capillitial threads

The direction of spiral ornamentation on the capillitial threads may be a useful taxonomic character for certain species. Most monographs do not mention this character. One reason may be that the terminology has been confusing; the terms "dextrorse" and "sinistrorse" are mostly used differently today than in older myxomycete literature. We have adopted these terms as defined by Snell \& Dick (1971), using "dextrorse" for describing a spiral rising clockwise towards the observer. The direction of the spirals has been constant within the species throughout the material included in this study. Spirals on the capillitium are sinistrorse in Trichia brunnea and Arcyria elaterensis but dextrorse in A. stipata. 


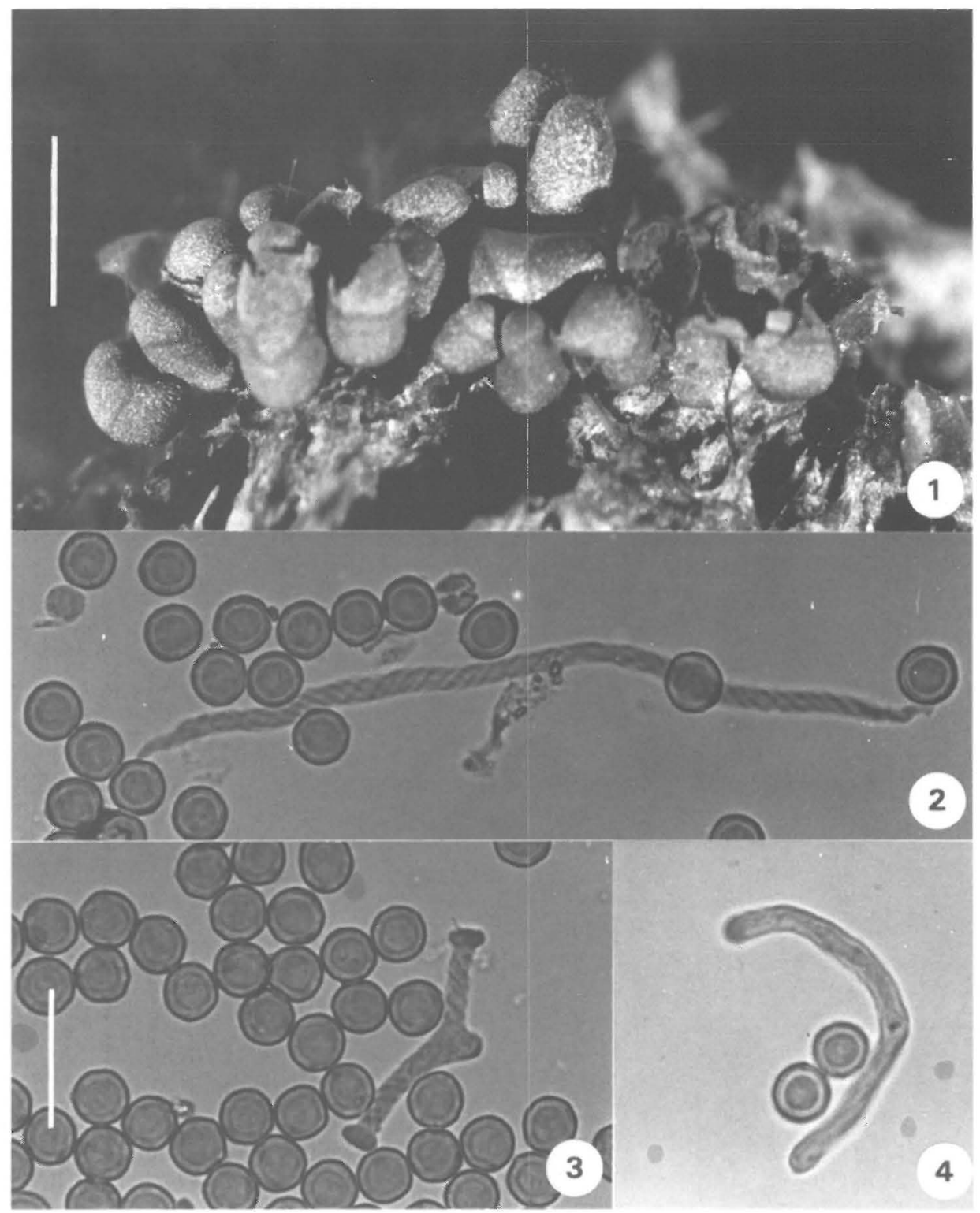

Figs. 1-4. Trichia brunnea (Moravec s. num., holotype of Hemitrichia stipata var. fusca). - 1: Habit, group of sporangia on reindeer dung. 2-4: Spores and capillitium showing variation in ornamentation and tips of free capillitium segments. Spores are thick-walled. - Bars: Fig. $1=1 \mathrm{~mm}$, Fig. $3=20 \mu \mathrm{m}$. Figs. $2-4$ are the same magnification.

\section{Trichia brunnea J.J.Cox}

Hemitrichia stipata var. fusca Z.Moravec was described from a moist chamber culture of reindeer dung collected in Norway (Moravec 1968). The type collection (Moravec s. num., 1965, PRM) consists of small groups of dark sporangia that blend in with the background (Fig. 1). It has been compared with the type collection (Cox 570, UC) of Trichia brunnea J.J.Cox and found to be the same species. The following description is based on the type collection of 
Figs. 5, 6. Trichia brunnea (Lundqvist 14925-d), SEMs. - 5: Capillitial thread with sinistrorse spiral ornamentation. 6: Spore. - Bars: Fig. $5=5$ $\mu \mathrm{m}$, Fig. $6=2 \mu \mathrm{m}$.

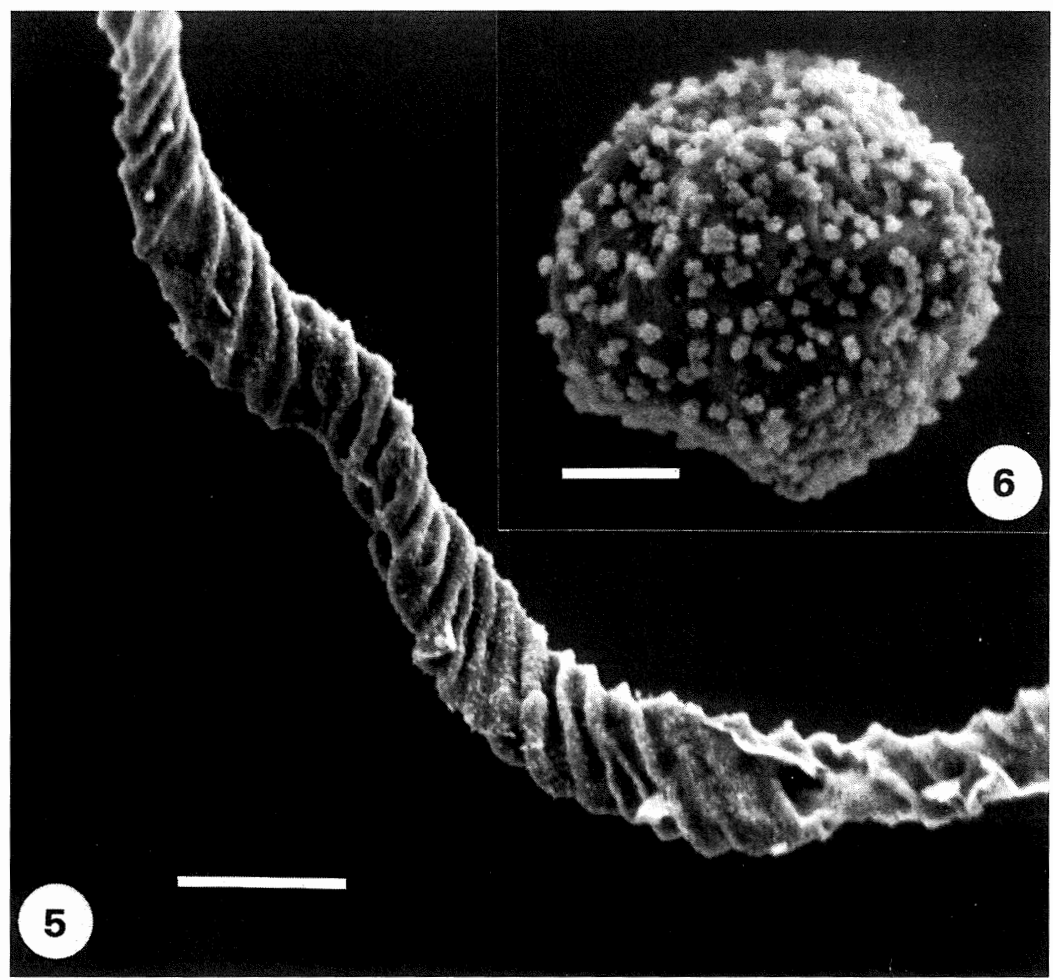

Hemitrichia stipata var. fusca. It broadens and deviates in some respects from the original description of Trichia brunnea (Cox 1981).

Sporangia gregarious to densely heaped, subsessile to distinctly stalked, ovoid or pearshaped to short-cylindric, rounded at apex, total height $0.7-1.0(-1.2) \mathrm{mm}$, dark olivaceous brown. Stalks up to $0.4 \mathrm{~mm}$ long, filled with rounded cells $8-15 \mu \mathrm{m}$ in diam. Peridium thin, lustrous and somewhat iridescent with fine undulations 8-10 $\mu \mathrm{m}$ in extension, long-persistent, dehiscing irregularly from above, leaving a deep but sometimes poorly defined and irregular basal cup. Capillitium predominantly of free unbranched elaters, partly of branched threads forming an incomplete network, ornamentation of $3(-4)$ distinct, sinistrorse spiral bands (Fig. 5), sometimes poorly defined (Fig. 4) or entirely missing on individual segment or portions of the threads; free elaters (Figs. 2-4) mostly 40-200 $\mu \mathrm{m}$ long, 3.5-4.0 $\mu \mathrm{m}$ wide, pale yellow in transmitted light, with ends rounded, abruptly narrowed, sometimes with the spirals excurrent as one or two points or hooks, or ending in an abruptly flattened swelling (Fig. 3). Spores dark brown in mass, olivaceous yellow in transmitted light, 8.5-9 $\mu \mathrm{m}$ in diam., almost smooth under the light microscope but with a few large warts giving the spores a slightly angular outline, spore wall $0.8-1.0 \mu \mathrm{m}$ thick.

The number of spirals on the elaters of Trichia brunnea is three (or four), not two as mentioned in previous literature. The elaters are wider and the spores somewhat smaller than in the protologue. Diagnostic characters are the dark sporangia with iridescent peridium, the free elaters bearing three sinistrorse spirals, and the dark, thick-walled spores. In general habit the sporangia resemble Arcyria, portions of the capillitium are branched, and the spore ornamentation is reminiscent of that in several species of Arcyria.

Trichia brunnea is a true coprophilous species. It is known from three localities. All collections are from moist chamber cultures on herbivore (cow, horse, reindeer) dung. The evenly thickened spore wall may be an adaptation to passage through the intestinal tract of herbiv- 
ores, requiring the action of digestive juices on the spore wall before germination can take place (cfr. Kelleromyxa fimicola, Eliasson et al. 1991, fig. 13).

Specimens studied: U.S.A. California, Modoc Co., State Hwy. 299, Canby, 1314 m, 1978 Cox 570 (UC, holotype of Trichia brunnea J.J.Cox). Norway. Hordaland, alt. $1300 \mathrm{~m}, 1965$ Moravec s. num. (PRM, holotype of Hemitrichia stipata var. fusca Z.Moravec). Montenegro. Durmitor National Park, Zabljak, 1984 Lundqvist 14925-d (GB, S).

\section{Arcyria elaterensis Mulleavy}

In the presence of both free elaters and a branched capillitium, Trichia brunnea resembles Arcyria elaterensis Mulleavy. Further similarities are the gregarious sporangia, the sinistrorse spiral ornamentation and frequent occurrence of clavate tips on the elaters, the rounded cells filling up the interior of the stalk, and the coprophilous habitat. Differences, based on the type of $A$. elaterensis (U.S.A, California, Contra Costa County, Briones Regional Park, Mulleavy no. 648 ; UC), are the brighter, yellowish brown sporangia of the latter species, the much more frequent occurrence of branches on the capillitium, the lighter and more thin-walled (ca. $0.4 \mu \mathrm{m}$ ) spores, and the more faintly marked spiral ornamentation on the capillitial threads, although spirals may be distinct in some portions of the capillitium (Mulleavy 1977, fig. 7). In contrast, the dark iridescent sporangia and dark thick-walled spores separate Trichia brunnea.

Differences among genera of Myxomycetes are sometimes vague and there are several examples of transitional species merging into two different genera. Arcyria elaterensis appears to be a borderline species between Arcyria and Trichia. Emphasizing the presence of spiral bands on the capillitial threads, Lado (in Lado \& Pando 1997) transferred A. elaterensis to Trichia. Although $T$. brunnea and A. elaterensis have several features in common, parts of the capillitium of the latter species are branched in an arcyrioid manner, and the spirals on the capillitial threads are mostly faintly marked and not of the type seen in Trichia. Portions of the capillitium may be completely devoid of spiral ornamentation. In our opinion, Arcyria elaterensis should be retained in this genus until its true phyloge- netic relationship can be proven through molecular techniques.

\section{Arcyria stipata (Schwein.) Lister}

The presence of free elaters distinguishes Arcyria elaterensis from the variable A. stipata (Schwein.) Lister, but the two species are similar in habit and colour of the fructifications. The latter species, originally described as Leangium stipatum Schwein. (Schweinitz 1832), is one of the transitional species between Arcyria and Hemitrichia. Schweinitz' original specimen of Leangium stipatum (in PENN), referred to as no. 2304-3 in his Synopsis Fungorum and marked with the same number, is a tightly aggregated group of sporangia on bark of decaying wood. The fruiting is about $10 \mathrm{~mm}$ across. The sporangia are subsessile or short-stalked; the stalk filled with rounded cells ca $15 \mu \mathrm{m}$ in diam. The spore mass is yellowish brown or greyish brown. Peridial fragments are transparent, smooth or with faint wrinkled or fan-like markings towards the base of the sporangium. The capillitium is netted and clearly arcyrioid with the threads bearing ornamentation of projections confluent into dense dextrorse spirals. The spores are ca $8 \mu \mathrm{m}$, very faintly ornamented, appearing smooth with the light microscope.

Leangium stipatum was transferred to Hemiarcyria by Rostafinski (1876), to Arcyria by Lister (1894), and to Hemitrichia by Macbride (1899). Most recent monographs retain it in Arcyria. This unstable generic position stems from the variable structure and ornamentation of the capillitial threads. The most characteristic ornamentation is faintly marked spirals bearing a comb-like or helicoidal crest of processes. Some specimens have capillitial threads with ornamentation that varies from very faint spirals, sometimes totally lacking, to spirals intermixed with cogs, spines, half-rings, or reticulations. In other specimens, the capillitial threads may exhibit more prominent spirals. The degree of branching of the capillitium may vary as may frequency of free ends and swellings. In a SEM study (Rammeloo 1986) based on four different specimens of Arcyria stipata, none of which was the type, the capillitial threads had either various processes arranged helicoidally, or faint to distinct uneven ridges bearing various minor processes. Smooth spirals of the Trichia or Hemitrichia type could 
not be demonstrated. The original specimen of Leangium stipatum differs from most specimens of Arcyria stipata in the dense spirals on the capillitial threads. Apart from Schweinitz' original specimen, three additional specimens of $A$. stipata have been studied, all from the United States (Thaxter 1228, Connecticut; Piquet s. num., Massachusetts; Darker 546, Massachusetts; all in GB). Although there is some variability in the capillitial system, none has free elaters and the spiral ornamentation is dextrorse throughout.

Nannenga-Bremekamp (1982) suggested inclusion of Hemitrichia imperialis G.Lister in Arcyria stipata mainly on grounds of birefringence characteristics in polarized light. The taxonomic delimitation of Arcyria stipata requires further study.

Acknowledgements. We thank the curators of herbaria PENN, PRM, and UC for loans of the type specimens used in this study.

\section{References}

Blackwell, M. \& Gilbertson, R. L. 1980: Sonoran desert myxomycetes. - Mycotaxon 11: 139-149.

Brummitt, R. K. \& Powell, C. E. 1992: Authors of plant names. - Royal Botanic Gardens, Kew.

Chung, C.-H. \& Liu, C.BH. 1995: First report of fimicolous myxomycetes from Taiwan. - Fung. Sci. 10: 33-35.

Chung, C.-H. \& Liu, C.-H. 1996: More fimicolous myxomycetes from Taiwan. - Taiwania 41: 259264.

Cochet, S. \& Bozonnet, J. 1984: Les Myxomycètes de France. Nouveautés et compléments (II). - Bull. Soc. Myc. Fr. 100: 39-64.

Cox, J. J. 1981: Notes on coprophilous myxomycetes from the western United States. - Mycologia 73: 741-747.

Critchfield, R. L. \& Demaree, R. S. 1991: Annotated checklist of California Myxomycetes. - Madroño 38: 45-56.

Eliasson, U. H., Keller, H. W. \& Schoknecht, J. D. 1991: Kelleromyxa, a new generic name for Licea fimicola (Myxomycetes). - Mycol. Res. 95: 1201-1207.

Eliasson, U. \& Lundqvist, N. 1979: Fimicolous myxomycetes. - Bot. Notiser 132: 551-568.

Farr, M. L. 1982: Notes on Myxomycetes. III. - Mycologia 74: 339-343.

García-Zorrón, N. 1977: Mixomicetos coprofilos del Uruguay. - Rev. Biol. Urug. 5: 47-50.

Gilert, E. 1990: On the identity of Perichaena liceoides (Myxomycetes). - Mycol. Res. 94: 698-704.

Gilert, E. 1995: Taxonomic evaluation of the myxo- mycete Calonema luteolum. - Mycol. Res. 99: 311316.

Gøtzsche, H. F. 1989: Myxomycetes from Greenland. Opera Bot. 100: 93-103.

Hertel, R. J. G. 1962: Contribuiçao ao estudo ecológico dos Myxogasteres (Myxophyta). - Bol. Univ. Paraná (Botanica) 1: 1-48.

Ing, B. 1967: Notes on Myxomycetes. II. - Trans. Brit. Mycol. Soc. 50: 555-562.

Ing, B. \& Spooner, B. M. 1994: Myxomycetes from the Kimberley region, western Australia. - Bot. J. Linn. Soc. 116: 71-76.

Keller, H. W., Aldrich, H. C., Brooks, T. E. \& Schoknecht, J. D. 1975: The taxonomic status of Badhamia ovispora: a myxomycete with unique spores. - Mycologia 67: 1001-1011.

Keller, H. W. \& Eliasson, U. H. 1992: Taxonomic evaluation of Perichaena depressa and P. quadrata based on controlled cultivation, with additional observations on the genus. - Mycol. Res. 96: 1085-1097.

Keller, H. W. \& Schoknecht, J. D. 1989a: Life cycle of a new annulate-spored species of Didymium. - Mycologia 81: 248-265.

Keller, H. W. \& Schoknecht, J. D. 1989b: Spore-tospore culture of Physarum spinisporum and its transfer to Badhamia. - Mycologia 81: 631-636.

Keller, H. W. \& Schoknecht, J. D. 1989c: Spore-tospore cultivation of a new wrinkled-reticulate-spored Badhamia. - Mycologia 81: 783-789.

Kowalski, D. T. \& Curtis, D. H. 1968: New records of myxomycetes from California III. - Madroño 19: 246-249.

Krug, J. C., Benny, G. L. \& Keller, H. W. (in press): Coprophilous Fungi. - In: Mueller, G. M., Bills, G., \& Foster, M. S. (eds), Measuring and Monitoring Biological Diversity: Standard Methods for Fungi. Smithsonian Press, Washington.

Lado, C. \& Pando, F. 1997: Myxomycetes, I. Ceratiomyxales, Echinosteliales, Liceales, Trichiales. - Flora Mycologica Iberica 2. Real Jardin Botánico Madrid, Gebrüder Borntraeger, Berlin.

Lakhanpal, T. N. \& Mukerji, K. G. 1975: Taxonomic studies on Indian myxomycetes. VII. The genus $\mathrm{Li}$ cea. - Kavaka 3: 101-105.

Lakhanpal, T. N. \& Mukerji, K. C. 1978: Taxonomic studies on Indian myxomycetes. XI. Some new records of Didymiaceae. - J. Indian Bot. Soc. 57: 174-180.

Lakhanpal, T. N. \& Mukerji, K. G. 1981: Taxonomy of the Indian myxomycetes. - Bibl. Mycol. 78: 1-531. J. Cramer, Vaduz.

Lister, A. 1894: A monograph of the Mycetozoa. British Museum, London.

Macbride, T. H. 1899: The North-American slimemoulds. - New York.

Merrill, R. A. 1969: A preliminary survey of the coprophilous myxomycetes of California. - Master's Thesis, California State Univ., Chico.

Mitchel, D. H. \& Chapman, S. W. 1980: Notes on Colorado fungi IV: Myxomycetes. - Mycotaxon 10: 299 349.

Moravec, Z. 1968: Remarks on some coprophilous fungi in Norway. - Ceská Mykol. 22: 301-309. 
Mulleavy, P. 1977: The description and laboratory cultivation of Arcyria elaterensis, a new species of Myxomycetes. - Mycologia 69: 693-700.

Nannenga-Bremekamp, N. E. 1982: Notes on Myxomycetes. XXI. The use of polarized light as an aid in the taxonomy of the Trichiales. - Proc. Kon. Ned. Akad. Wet., Ser. C, 85: 541-562.

Nannenga-Bremekamp, N. E., Mukerji, K. G. \& Singh, N. 1979: On two coprophilous myxomycetes from India. - Proc. Kon. Ned. Akad. Wet., Ser. C, 82: 217221.

Rammeloo, J. 1978: Calonema luteolum Kowalski (Myxomycetes) found at the Hebrides (Scotland). Bull. Nat. Plantentuin Belg. 48: 241-242.

Rammeloo, J. 1986: Icones Mycologicae 111-130. Nationale Plantentuin van België. Meise.

Rostafinski, J. T. 1876: Sluzowce Monografia. Dotatek 8: 1-43. - Strassburg.
Schweinitz, L. D. de 1832: Synopsis fungorum in America boreali media degentium. - Trans. Am. Phil. Soc. 2, 4: 141-316.

Singh, C. S. 1984: Successional studies of fungi on mammalian dung. - Acta Mycologica 20: 105-120.

Stephenson, S. L. 1989: Distribution and ecology of Myxomycetes in temperate forests. II. Patterns of occurrence on bark surface of living trees, leaf litter, and dung. - Mycologia 81: 608-621.

Snell, W. H. \& Dick, E. A. 1971: A glossary of mycology. - Harvard University Press, Cambridge, Massachusetts.

Zeller, L. \& Tóth, S. 1976-1977: Myxomycetes data from Hungary II. - Ann. Universitatis Scient. Budap. Rolando Eötvös nom. Sect. Biol. 18-19: 137-154.

Received on 27 November 1998 